\title{
Pengaruh Good Corporate Governance Terhadap Firm Value Yang Dimediasi Oleh Return On Assets pada Perusahaan Sektor Pertambangan Batubara yang Terdaftar di Bursa Efek Indonesia
}

\author{
Rini Agustina \\ Universitas Sumatera Utara \\ riniagustina4@gmail.com
}

\begin{abstract}
Abstrak
Penelitian ini dilakukan untuk menguji pengaruh Good Corporate Governance terhadap Firm Value dengan Return On Assets sebagai variabel intervening. GCG yang digunakan dalam penelitian ini adalah indikator kepemilikan manajerial dan kepemilikan institusional. Populasi dalam penelitian ini adalah perusahaan manufaktur yang terdaftar di Bursa Efek Indonesia selama periode 2015- 2018. Pemilihan sampel dilakukan dengan metode purposive sampling dari 22 perusahaan sektor pertambangan batubara diperoleh 11 perusahaan sampel yang memenuhi syarat. Teknik analisis data yang digunakan adalah analisis rasio keuangan untuk mengetahui kondisi rasio keuangan perusahaan dari variabel yang diteliti, analisis jalur (Path Analysis) untuk mengetahui besarnya sumbangan (kontribusi) yang ditunjukkan oleh koefisien jalur pada setiap diagram jalur, uji hipotesis menggunakan t-statistik dan F-statistik selain itu juga dilakukan uji asumsi klasik yang meliputi uji normalitas, uji multikolinearitas, uji heteroskedastisitas dan uji autokorelasi. Selama periode pengamatan menunjukkan bahwa data penelitian berdistribusi normal. Berdasarkan uji normalitas, uji multikolinearitas, uji heteroskedastisitas dan uji autokorelasi tidak ditemukan variabel yang menyimpang dari asumsi klasik. Hasil penelitian ini menunjukkan bahwa: 1) GCG yang diproksi Kepemilikan Manajerial memiliki nilai negatif dan tidak signifikan terhadap FV, dan Kepemilikan Institusional memiliki nilai negatif dan tidak signifikan terhadap FV 2) GCG yang di proksikan dengan Kepemilikan Manajerial menyatakan nilai negatif dan tidak signifikan terhadap ROA,dan hasil pengujian Kepemilikan Institusional terhadap ROA menyatakan bahwa nilai positif dan tidak signifikan terhadap ROA, 3) ROA memiliki nilai negatif dan berpengaruh signifikan terhadap FV, 4) GCG terhadap FV yang dimediasi oleh ROA memiliki pengaruh. Disarankan pada penelitian berikutnya untuk menambah variabel lainnya dalam penelitian ini.
\end{abstract}

Kata kunci: Good Corporate Governance (GCG), Return On Assets (ROA), Firm Value (PBV).

Jurnal Insitusi Politeknik Ganesha Medan

Juripol, Volume 4 Nomor 1 Maret 2021

114 


\section{PENDAHULUAN}

Setiap perusahaan untuk mendirikan perusahaanya harus memikirkan tujuan yang jelas. Dimana tujuan tersebut terdiri untuk mencapai keuntungan maksimal, selain itu perusahaan juga memiliki tujuan yang lainnya yaitu tujuan jangka panjang dimana perusahaan ingin memberikan keuntungan bagi pemilik perusahaan (stakeholder) dan untuk meningkatkan nilai perusahaan secara maksimal yang dilihat dari harga suatu saham perusahaan (Isti'adah, 2015, hal. 2). Adapun maksud dari nilai perusahaan adalah nilai keuntungan untuk masa yang akan datang yang telah diharapkan dan dihitung kembali dengan suku bunga yang tepat (Basri, 2016, hal. 2). Dalam pandangan lain, nilai perusahaan adalah kinerja perusahaan yang dicerminkan oleh harga saham yang dibentuk oleh permintaan dan penawaran pasar modal yang merefleksikan penilaian masyarakat terhadap kinerja perusahaan (Harmono, 2009, hal. 233). Bagi setiap perusahaan, sebuah nilai perusahaan sangat penting bagi perusahaan. Namun, didalam proses untuk menjalankan dan menanamkan nilai perusahaan sangatlah tidak mudah. Nilai perusahaan dipengaruhi oleh banyak faktor diantaranya tata kelola yang baik (Good Corporate Governance) dan kinerja keuangan yang baik pula (Santoso, 2017, hal. 67). Meliputi kinerja keungan diteliti dengan menggunakan rasio keuangan seperti ROA (Return On Aset).

Namun demikian, permasalahan didalam Perusahaan Pertambangan Sektor Pertambangan Batubara yang terdafar di Bursa Efek Indonesia adalah untuk memaksimalkan nilai perusahaan akan muncul konflik kepentingan antara Agent (pihak manajemen) dan Principal (pemilik perusahaan) atau sering disebut dengan Agency Problem. Sering terjadi didalam perusahaan bahwa Agent dan Principal memiliki tujuan dan kepentingan yang saling bertentangan. Dimana, pihak manajemen akan lebih mementingkan pribadinya tanpa memeikirkan kesejahteraan pemilik perusahaan dan tanpa mementingkan nilai perusahaan. Nilai perusahaan akan naik apabila pemilik perusahaan bisa mengendalikan perilaku manajemen agar tidak menghamburkan resources perusahaan, baik dalam bentuk investasi yang tidak layak maupun dalam bentuk yang layak. Corporate Governance merupakan suatu sistem yang mengatur dan mengendalikan perusahaan yang diharapkan dapat memberikan dan meningkatkan nilai perusahaan kepada para pemegang saham. Oleh karena itu, penggunaan Good Corporate Governance akan dapat meningkatkannya nilai suatu perusahaan.

Pada era saat ini, banyak perusahaan manufaktur yang tergantung kepada modal ekuiti dan pinjaman, untuk melakukan pembiayaan kegiatan yang akan dilakukan perusahaan, untuk melakukan sebuah investasi dan menciptakan pertumbuhan yang baru (Basri, 2016, hal. 5). Dalam kebijakan lembaga keuangan yang bersekala besar dalam pembiayaan perusahaan yang melalui pinjaman atau pemberian modal ke perusahaan, perusahaan harus memasukan syarat-syarat untuk melaksanakan coporate governance pada perusahaan yang didanainya (Sutedi, 2012, hal. 4). Industri yang dilakukan oleh perusahaan manufaktur menguasai perusahaan-perusahaan yang terdaftar didalam Bursa Efek Indonesia (BEI), dan industri manufaktur penyebab utama perkembangan industri didalam sebuah negara (Basri, 2016, hal. 6). Tinggi rendahnya suatu nilai perusahaan seperti diatas dipengaruhi oleh beberapa faktor, diantaranya keputusan pendanaan dan struktur kepemilikan (Wahyudi \& Pawestri, 2006), profitabilitas (Dewi \& Wirajaya, 2013).

Jurnal Insitusi Politeknik Ganesha Medan 
Faktor-faktor lainnya yang juga mempengaruhi nilai perusahaan adalah Good Corporate Governance (Santoso, 2017).

Dalam penelitian ini tidak semua faktor yang mempengaruhi nilai perusahaan diatas yang akan diteliti. Peneliti hanya berfokus pada Good Corporate Governance. Beberapa penelitian yang menghubungkan antara Good Corporate Governance dengan nilai perusahaan sudah banyak dilakukan. Diantaranya penelitian Retno (2012) yang menunjukkan bahwa Good Corporate Governance berpengaruh positif terhadap nilai perusahaan dengan variabel kontrol (Size) dan Leverage pada perusahaan yang terdaftar di BEI periode 2007-2010. Hasil penelitian yang lain menunjukkan bahwa kinerja keuangan berpengaruh terhadap nilai perusahaan, sedangkan Good Corporate Governance bukanlah variabel yang memoderasi hubungan kinerja keuangan dengan nilai perusahaan (Pertiwi \& Pratama, 2013). Agus Santoso mengatakan bahwa "Adanya hubungan antara Good Corporate Governance dengan nilai perusahaan dan juga kinerja keuangan didalam perusahaan". Hasil penelitian lain yaitu menunjukan bahwa adanya pengaruh Good Corporate Governance terhadap nilai perusahaan yang mana kinerja keuangannya manjadi variabel intervreningnya (Ratih \& Setyarini, 2014).

\section{Firm Value}

\section{LANDASAN TEORI}

Nilai perusahaan adalah suatu nilai pasar yang terdiri dari surat berharga hutang dan ekuitas perusahaan yang telah beredar (Martin, John D. ; Petty, J. William; Keown, Arthur J.; Scott, 2004, hal. 116). Berkaitannya dengan hal tersebut, nilai perusahaan adalah harga jual yang dianggap layak bagi para calon investor, sehingga mereka ingin membayarnya, jika suatu saat perusahaan akan dibubarkan (likuidasi) (R. Dewi, Topowijono, \& Sulasmiyati, 2015, hal 3). Beberapa pendapat lain tentang nilai perusahaan adalah suatu nilai paling berharga untuk pemegang saham, karena akan tercermin dari harga pasar sahamnya (Basri, 2016, hal. 23). Nilai perusahaan adalah nilai yang telah di pikirkan dan dihitung kembali dengan suku bunga yang tepat untuk masa depan perusahaan yang akan datang (Dj, Artini, \& Suarjaya, 2012, hal. 131).

Dari beberapa penjelasan tentang pengertian nilai perusahaan, dengan demikian dapat disimpulkan bahwa nilai perusahaan adalah suatu nilai pasar yang telah dipikiran atau dirancang dan dihitung kembali dengan suku bunga yang tepat demi masa depan perusahaan dan menjadi hal yang paling berharga yang dilihat bagi para pemegang saham.

Adapun yang mempengaruhi suatu nilai perusahaan dari beberapa penelitian sebagai berikut : (1) Keputusan pendanaan sering diartikan sebagai keputusan yang berkaitan dengan struktur keuangan perusahaan, dan dari pendanaan dapat meningkatkan suatu nilai perusahaan (Fenandar, 2012, hal. 15), (2) Struktur kepemilikan dapat mempengaruhi jalannya perusahaan yang melalui kinerja keuangan untuk mencapai tujuan yang diinginkan, yaitu meningkatkan nilai perusahaan (Wahyudi, U. dan Pawestri, H. P., 2006, hal. 2), (3) Profitabilitas adalah kemampuan perusahaan dalam menggapai laba, dimana jika investor menaman saham terhadap perusahaan adalah untuk mendapatkan return, semakin tinggi laba yang diperoleh oleh perusahaan maka tinggi juga return yang diharapkan investor dan menjadikan nilai perusahaan menjadi lebih baik lagi (Sri et al., 2013, hal. 363).

Jurnal Insitusi Politeknik Ganesha Medan 
Untuk menghitung nilai perusahaan bisa dilakukan dengan beberapa indikator, dimana indikator tersebut terdiri dari PER (Price Earning Ratio), PBV (Price to Book Value) dan Tobin's Q (Basri, 2016, hal. 24). PER menunjukan perbandingan antara closing price dengan jumlah laba per lembar saham (earning per share) (Wahyudi, U. dan Pawestri H. P, 2006, hal. 8). PBV sering digunakan dalam menentukan pengambilan keputusan investasi yang mempengaruhi harga saham (Sitepu, N. R. dan Wibisono, C. H. , 2013, hal.3). Tobin's Q indikator yang sering digunakan dalam menunjukan nilai perusahaan, yang menunjukan suatu performa manajemen dalam mengelola aktivitas perusahaan (Rahmawati, D et al., 2015, hal. 3).

$$
\text { Price to Book Value }=\frac{\text { Harga Saham }}{\text { Nilai Buku Per Lembar Saham }}
$$

\section{Return On Assets}

Return On Assets (ROA) salah satu rasio profitabilitas dalam menganalisa laporan keuangan untuk melihat proses kinerja keuangan perusahaan. Dalam melakukan investasi, investor akan mempertimbangkan sebaik mungkin akan kemana mereka menanamkan modalnya yang akan diinvestasikan (Jufrizen \& Fatin, 2020). Return On Assets termasuk rasio untuk menunjukan hasil perputaran atas pemakaiannya aset untuk terbentuknya laba bersih. Menurut (Sari \& Jufrizen, 2019, Hal. 198) ROA (Return On Assets) merupakan kemampuan bagi perusahaan dengan menggunakan semua aktiva yang dimiliki untuk menghasilkan laba setelah pajak. Pendapat lain tentang ROA adalah sesuatu yang menggambarkan sejauh mana aset-aset perusahaan berkembang untuk menghasilkan laba didalam perusahaan (Kamal, 2017, Hal. 69).

Dari beberapa teori diatas, dapat disimpulkan bahwa pengertian Return On Assets (ROA) adalah suatu teknik dalam pengelolaan keuangan didalam perusahaan untuk melihat kinerja keuangan perusahaan, agar mencapai tujuan yang sudah ditetapkan seperti pencapaian laba yang diharapkan.

Menurut (Munawir, 2016, Hal. 89) terdapat dua faktor yang mempengaruhi return on assets.(1)Turnover from Operating Assets (tingkat perputaran aktiva yang digunakan untuk pengoperasian), (2)Profit Margin, Besarnya keuntungan operasi yang dinyatakan dalam persentase dan jumlah penjualan bersih. Profit Margin dapat mengukut tingkat keuntungan yang dapat dicapai oelh perusahaan dihubungkan dengan tingkat penjualannya. Menurut pendapat lain, faktor-faktor yang mempengaruhi return on assets menurut (Riyanto, 2010, Hal. 37) : (1)Profit Margin, perbandingan antara Net Operating Income dengan Net Sales, (2) Tingkat peputaran aktiva usaha yaitu kecepatan berputarnya Operating Assets dalam suatu periode tertentu.

Menurut (Rambe, Gunawan, Julita, Parlindunga, \& Gultom, 2017, Hal. 71), didalam bukunya mengatakan bahwa rumus ROA sebagai berikut :

$$
\text { Return On Assets }=\frac{\text { Laba Bersih Setelah Pajak }}{\text { Total Aktiva }}
$$




\section{Good Corporate Governance}

Good Corporate Governance (GCG) merupakan konsep yang baik yang diajukan demi meningkatkan kinerja perusahaan yang melalui monitoring kinerja manajemen dan manajemen akuntabilitas terhadap stakeholder dengan berdasarkan peraturan (Basri, 2016, hal. 6). Menurut pendapat lain GCG merupakan rangkaian proses, atau pengontrolan yang baik suatu perusahaaan (Pertiwi \& Pratama, 2013, hal. 120). Dengan begitu kesimpulan dari beberapa pengertian diatas adalah, GCG merupakan suatu sistem atau konsep yang diterapkan oleh perusahaan untuk mengelola, mengatur, memproses, dengan baik untuk menciptakan nilai perusahaan yang baik pula.

Ada dua faktor yang dapat diterapkan didalam good corporate governance yaitu faktor internal dan eksternal :(1) Faktor Internal merupakan faktor yang mendorong keberhasilan dalam menerapkan GCG yang berasal dari dalam perusahaan,(2) Faktor Eksternal merupakan faktor yang berasal dari luar perusahaan yang mendorong keberhasilan dalam menerapkan GCG,

Menurut pendapat (Irmawatih, 2016) didalam penelitiannya mengatakan bahwa good corporate governance mempunya beberapa faktor-faktor yang mempengaruhi, yaitu ; (1)Profitabilitas, mampunya perusahaan dalam pencapaian laba yang efektif dan efisien dari aktivitas operasi didalam perusahaan pada tingkta penjualan;(2)Leverage, rasio yang menunjukan seberapa besar aset perusahaan yang dimiliki untuk perusahaan dalam membiayai dana utang dari kreditor; (3)Ukuran Perusahaan, dalam mengukur perusahaan bisa dilihat dari beberapa aspek, pada total aset, total penjualan kapitalisasi besar, jumlah tenaga kerja, dan sebagiannya.(4)Konsentrasi Kepemilikan, gambaran yang menunjukan struktur para pemangku kepentingan didalam perusahaan.

Dari beberapa pendapat faktor-faktor yang mempengaruhi good corporate governance diatas, dapat disimpulkan bahwa, perusahaan harus benar dalam menata pengelolaan perusahaan, sebab akan berakibat pada pendapatan dan profitabilitas didalam perusahaan, dan akan memperbaiki gambaran perusahaan yang baik dimata para pemangku pemegang saham.

Untuk mengukur GCG bisa dilakukan dengan melihat dari indikator, kepemilikan manajerial dan kepemilikan institusional (Basri, 2016, hal. 29-30). (1) Kepemilikan Manjerial Kepemilikan Manajerial meruapakan situasi dimana manajer yang memiliki saham dan sekaligus pemegang saham perusahaan, dan hal ini merupakan informasi yang penting, dan diinformasikan dalam catatan atas laporan keuangan perusahaan (Basri, 2016, hal. 29). (2)Kepemilikan Institusional Kepemilikan Institusional merupakan saham atau kepemilikan yang dipegang dan dikuasai oleh pemerintah, institusi berbadan hukum, institusi luar negeri, dana perwalian, serta institusi lainnya yang terdaftar pada akhir tahun (Basri, 2016, hal. 29).

$$
\begin{aligned}
& \text { MNJR }=\frac{\sum \text { Saham yang dimiliki manajer, }, \text { komisaris, dan direksi }}{\sum \text { Saham yang beredar }} \\
& \mathrm{INST}=\frac{\sum \text { Saham yang dimiliki institusi }}{\sum \text { Saham yang beredar }}
\end{aligned}
$$

Jurnal Insitusi Politeknik Ganesha Medan 


\section{METODE PENELITIAN}

Pendekatan penelitian yang digunakan dalam penelitian ini adalah pendekatan asosiatif. Jenis data yang digunakan bersifat kuantitatif, yaitu berbentuk angka (Data Sekunder) dengan menggunakan skala rasio dengan berdasarkan formula yang dijadikan sebagai dasar pengukuran serta menggunakan alat analisis statistik berupa Path Analysis. Populasi dalam penelitian ini adalah seluruh pusahaan sektor Pertambangan Batubara yang terdaftar di Bursa Efek Indonesia sebanyak 22 perusahaan. Prosedur peilihan sampel dilakukan dengan teknik purposive sampling, maka sampel dalam penelitian ini sebanyak 11 perusahaan. Data sekunder dari penelitian ini diperoleh dari publikasi laporan keuangan perusahaan yang terdaftar di Bursa Efek Indonesia. Pengolahan data menggunakan perangkat lunak SPSS versi 21. Analisis statisitk inferensial dalam penelitian ini meliputi: uji asumsi klasik, regresi analisis jalur, uji hipotesis.

\section{HASIL DAN PEMBAHASAN}

Uji normalitas yang digunakan dalam penelitian ini yaitu grafik Normal P-P Plot of Regression Standardized Residual. Berikut adalah tabel hasil uji normalitas dengan menggunakan grafik Normal P-P Plot of Regression Standardized Residual sebagai berikut:

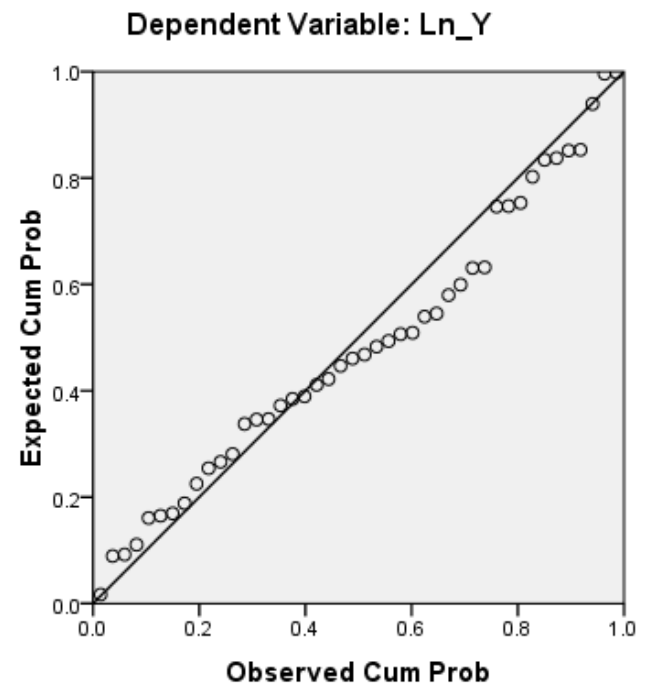

Gambar 1. Hasil P-Plot Normalitas Data

Berdasarkan grafik Normal P-P Plot of Regression Standardized Residual di atas, dapat dilihat bahwa penyebaran titik-titik mengikuti dan menyebar di garis diagonal. Maka dari itu dapat disimpulkam Normal P-P Plot of Regression Standardized Residual berdistribusi normal, sehingga memenuhi kriteria normalitas dan layak untuk dianalisis. 
Tabel 1. Uji Multikolinearitas

Coefficients ${ }^{\mathbf{a}}$

\begin{tabular}{|ll|l|l|}
\hline \multirow{2}{*}{\multicolumn{2}{|c|}{ Model }} & \multicolumn{2}{|l|}{ Collinearity Statistics } \\
\cline { 2 - 4 } & Tolerance & VIF \\
\hline 1 & (Constant) & & \\
& LN_X1 & .845 & 1.183 \\
LN_X2 & .828 & 1.207 \\
& LN_Z & .977 & 1.024 \\
\hline
\end{tabular}

a. Dependent Variable: LN_Y

Dari hasil uji yang ada, dapat disimpulkan bahwa tidak terjadi gejala multikolinearitas antara variabel independen maupun variabel mediasi yang diindikasikan dari nilai tolerance setiap variabel independen dan variabel intervening yang lebih besar dari 0,1 dan nilai VIF yang lebih kecil dari 10 .

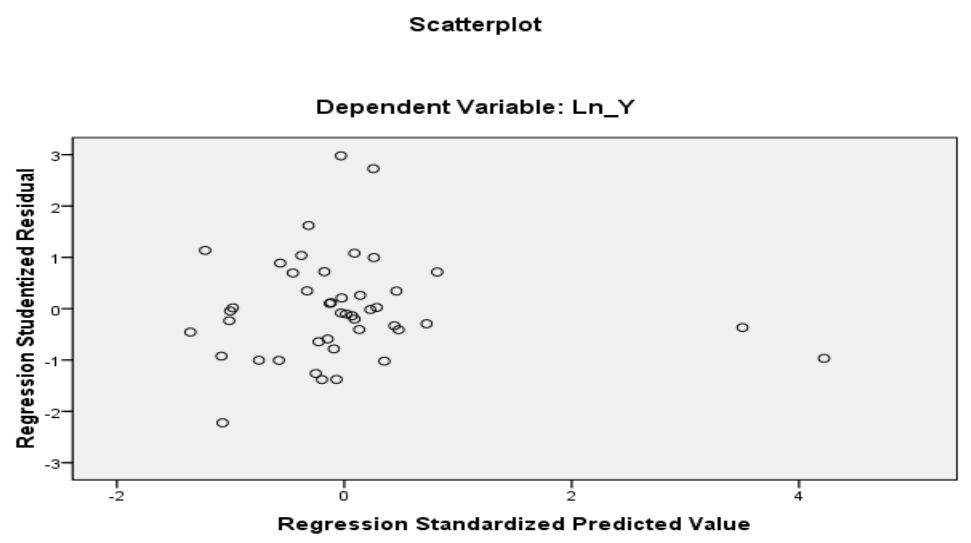

Gambar 2. Scatterplot Uji Heteroskedastisitas

Hal ini dapat disimpulkan bahwa tidak terjadi heterokedastisitas pada model regresi sehingga model regresi layak dipakai untuk melihat Price to Book Value perusahaan sektor pertambangan batubara yang terdaftar di Bursa Efek Indonesia berdasarkan masukan variabel independen Kepemilikan Manajerialdan Kepemilikan Institusionalserta variabel mediasi Return On Assets.

Tabel 2. Regresi Pertama Hasil Uji t

\section{Coefficients $^{a}$}

\begin{tabular}{|c|c|c|c|c|c|c|}
\hline \multirow{2}{*}{\multicolumn{2}{|c|}{ Model }} & \multicolumn{2}{|c|}{$\begin{array}{l}\text { Unstandardized } \\
\text { Coefficients }\end{array}$} & \multirow{2}{*}{\begin{tabular}{|l} 
Standardized \\
Coefficients \\
Beta \\
\end{tabular}} & \multirow[b]{2}{*}{$\mathrm{T}$} & \multirow[b]{2}{*}{ Sig. } \\
\hline & & B & Std. Error & & & \\
\hline \multirow[t]{3}{*}{1} & (Constant) & 3.324 & .115 & & 28.810 & .000 \\
\hline & Ln_X1 & -.013 & .207 & -.010 & -.061 & .952 \\
\hline & Ln_X2 & .098 & .106 & .156 & .928 & .359 \\
\hline
\end{tabular}

a. Dependent Variable: Ln_Z 
Dari hasil tersebut dapat dikatakan variabel $\mathrm{X}$ yaitu Good Corporate Governance yang diproksi dengan Kepemilikan Manajerial dan Kepemilikan Institusional tidak berpengaruh signifikan terhadap variabel Z Return On Assets (Ln_Z).

Tabel 3. Regresi Kedua Hasil Uji t Coefficients $^{\text {a }}$

\begin{tabular}{|c|c|c|c|c|c|c|}
\hline \multirow{2}{*}{\multicolumn{2}{|c|}{ Model }} & \multicolumn{2}{|c|}{$\begin{array}{l}\text { Unstandardized } \\
\text { Coefficients }\end{array}$} & \multirow{2}{*}{$\begin{array}{l}\text { Standardized } \\
\text { Coefficients } \\
\text { Beta } \\
\end{array}$} & \multirow[b]{2}{*}{$\mathrm{T}$} & \multirow[b]{2}{*}{ Sig. } \\
\hline & & B & Std. Error & & & \\
\hline \multirow[t]{4}{*}{1} & (Constant) & 2.078 & .582 & & 3.569 & .001 \\
\hline & Ln_X1 & -.266 & .227 & -.165 & -1.171 & .249 \\
\hline & Ln_X2 & -.158 & .117 & -.193 & -1.353 & .184 \\
\hline & Ln_Z & -.585 & .171 & -.450 & -3.422 & .001 \\
\hline
\end{tabular}

a. Dependent Variable: Ln_Y

Dari tabel di atas, diketahui nilai-nilai variabel bebas adalah sebagai berikut: (1) Pengaruh Good Corporate Governance yang diproksi dengan Kepemilikan Manajerial (Ln_X1) terhadap Firm Value (Ln_Y) memiliki nilai signifikan 0.249 dengan nilai beta sebesar -0.165. Dari hasil tersebut dapat dikatakan variabel Good Corporate Governance yang diproksi dengan Kepemilikan Manajerial tidak berpengaruh signifikan dan negatif terhadap variabel Firm Value (Ln_Y), (2) Pengaruh Good Corporate Governance yang diproksi dengan Kepemilikan Institusional (Ln_X2) terhadap Firm Value (Ln_Y) memiliki nilai signifikan 0.184 dengan nilai beta sebesar -0.193. Dari hasil tersebut dapat dikatakan variabel Good Corporate Governance yang diproksi dengan Kepemilikan Institusional tidak berpengaruh signifikan dan negatif terhadap variabel Firm Value (Ln_Y), (3) Pengaruh Return On Assets (Ln_Z) terhadap Firm Value (Ln_Y) memiliki nilai signifikan 0.001 dengan nilai beta sebesar -3.422. Dari hasil tersebut dapat dikatakan variabel Return On Assets berpengaruh signifikan dan negatif terhadap variabel Firm Value (Ln_Y).

Tabel 4. Hasil Uji F

ANOVA ${ }^{b}$

\begin{tabular}{|ll|l|l|l|l|l|}
\hline \multicolumn{2}{|l|}{ Model } & Sum of Squares & Df & Mean Square & F & Sig. \\
\hline 1 & Regression & 12.190 & 3 & 4.063 & 6.440 & $.001^{\mathrm{a}}$ \\
& Residual & 25.238 & 40 & .631 & & \\
& Total & 37.427 & 43 & & & \\
\hline
\end{tabular}

a. Predictors: (Constant), Ln_Z, Ln_X1, Ln_X2

b. Dependent Variable: Ln_Y

Berdasarkan tabel diatas, dapat dilihat dari nilai F sebesar 6.440 dengan nilai signifikan sebesar 0.001 lebih kecil dari $0.05(0.001<0.05)$. Hal ini menunjukkan bahwa Good Corporate Governance yang diproksi dengan Kepemilikan Manajerial 
(Ln_X1) dan Kepemilikan Institusional (Ln_X2) yang dimediasi oleh Return On Assets (Ln_Z) mempengaruhi secara similtan Firm Value (Ln_Y).

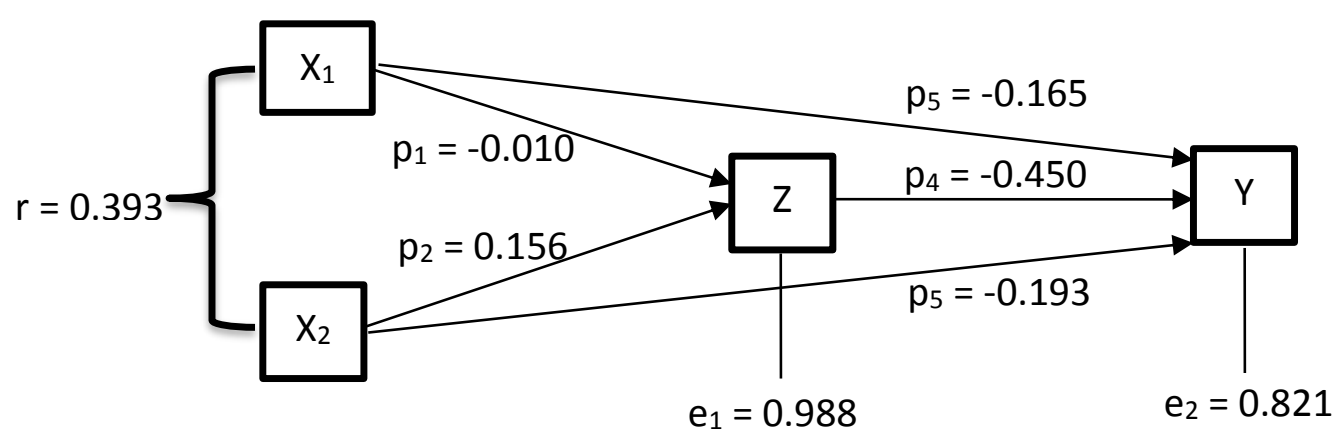

\section{Gambar.3 Sub-struktur (Pengaruh Kepemilikan Manajerial dan Kepemilikan Institusional Terhadap Firm Value Dimediasi Return On Assets)}

\section{PEMBAHASAN}

\section{Pengaruh Good Corporate Governance terhadap Firm Value}

Hasil pengujian ini menunjukan bahwa sektor Good Corporate Governance yang di proksikan dengan Kepemilikan Manajerial menunjukkan pengaruh sektor dan tidak signifikan terhadap Firm Value, yang dimana ketika nilai kepemilikan manjerial naik atau turun hal ini tidak akan mempengaruhi nilai Firm Value pada perusahaan sektor pertambangan batubara yang terdaftar di BEI tahun 2015-2018.

Menurut Permanasari dalam (Prastuti \& Budiasih, 2015) hal ini terjadi karena rendahnya saham yang dimiliki oleh manajemen mengakibatkan pihak manajemen belum merasa ikut memiliki perusahaan karena tidak semua keuntungan dapat dinikmati oleh manajemen yang menyebabkan pihak manajemen termotivasi untuk memaksimalkan utilitasnya sehingga merugikan pemegang saham. Selain itu dengan rendahnya kepemilikan saham oleh manajemen membuat kinerja manajemen juga cenderung rendah sehingga tidak mempengaruhi nilai perusahaan.

Hasil penelitian ini sejalan dengan penelitian yang dilakukan oleh (Prastuti \& Budiasih, 2015) yang menyatakan Nilai Perusahaan tidak dipengaruhi oleh Kepemilikan Manajerial dan hasil penelitian ini tidak sejalan dengan (Sholekah \& Venusita, 2014) yang menyatakan bahwa Kepemilikan Manajerial berpengaruh terhadap nilai perusahaan. Jika dilihat arah hubungannya memiliki pengaruh positif yang artinya semakin tinggi jumlah saham yang dimiliki oleh pihak manajemen perusahaan maka semakin tinggi pula nilai perusahaan.

Hasil pengujian Kepemilikan Institusional terhadap Firm Value memiliki hasil nilai sektore dan tidak signifikan hal ini menyatakan bahwa ketika terjadinya kenaikan atau penurunan pada nilai Kepemilikan Institusional tidak mempengaruhi nilai dari Firm Value pada perusahaan sektor pertambangan batubara yang tedfaftar di BEI tahun 2015-2018.

Menurut (Nurkhin, Wahyudin, \& Fajriah, 2017) hal ini terjadi karena perilaku variabel kepemilikan institusional tidak menunjukkan pengaruh terhadap nilai perusahaan dan tidak sesusai dengan pandangan teori keagenan. Teori ini menjelaskan bahwa adanya kesenjangan antara pihak prinsipal dan agen karena adanya benturan kepentingan. Adanya benturan kepentingan inilah yang 
menyebabkan adanya agency cost sebagai konsekuensi yang harus ditanggung perusahaan. Peningkatan kepemilikan institusional dalam perusahaan dinilai sebagai salah satu alternatif yang dapat mengurangi konflik keagenan yang terjadi, karena dengan adanya kepemilikan institusional pengawasan terhadap kinerja manajemen terjamin.

Hasil pengujian ini sejalan dengan peniltian yang dilakukan oleh (Wongso, 2013) yang menyatakan bahwa Kepemilikan Instisional berpengaruh sektore dan tidak signifikan terhadap Nilai perusahaan. Hasil ini tidak mendukung teori yang dimana Kepemilikan Institusional menambah proporsi pengawasan terhadap manajemen perusahaan dimana akan meningkat nilai perusahaan.

Hasil penelitian ini tidak sejalan dengan (Sukirni, 2012) yang menyatakan nilai Kepemilikan Institusional berpengaruh positif secara signifikan terhadap Nilai Perusahaan, semakin besar Kepemilikan Institusional maka semakin efisien.

\section{Pengaruh Good Coporate Governance terhadap Return On Assets}

Hasil pengujian ini menunjukan bahwa sektor Good Corporate Governance yang di proksikan dengan Kepemilikan Manajerial menyatakan nilai sektor dan tidak signifikan terhadap Return On Assets, yang dimana ketika nilai Kepemilikan Manajerial naik atau turun hal ini tidak mempengaruhi nilai dari Return On Assets pada perusahaan sektor pertambangan batubara tahun 2015-2018.

Menurut Christiawan dan Tarigan dalam (Wiranata \& Nugrahanti, 2013) hal ini menunjukan kinerja manajer sekaligus pemegang saham masih rendah dalam pengelolaan perusahaan, rasa kepemilikan manajer atas perusahaan tidak mampu membuat pencapaian yang optimal yang dimana biasanya keputusan manajerial dipandu oleh kepentingan mereka sendiri dibandingkan dengan manajer murni sebagai tenaga professional didalam perusahaan. Maka disimpulkan Kepemilikan Manjereial tidak berpengaruh secara signifikan terhadap Return On Assets.

Penelitian ini sejalan dengan (Aji, 2016) yang menyatakan bahwa kepemilikan saham oleh pihak manajer tidak berpengaruh terhadap Return On Assets, dengan adanya hal ini segala bentuk keputusan akan diambil sesuai yang disarankan langsung oleh pihak manajer. Penelitian ini tidak sejalan dengan (Maryanti \& Fithri, 2017) yang menyatakan bahwa Kepemilikan Manajerial secara parsial berpengaruh terhadap Kinerja Keuangan.

Hasil pengujian Kepemilikan Institusional terhadap Return On Assets menyatakan bahwa nilai positif dan tidak signifikan terhadap Return On Assets, yang dimana ketika nilai Kepemilikan Institusional mengalami kenaikan atau penurunan tidak akan mempengaruhi Return On Assets pada perusahaan ector batubara yang terdaftar di BEI tahun 2015-2018.

Hal ini mungkin terjadi dikarenakan adanya tujuan lain didalam perusahaan seperti tujuan politik maupun sektor. Tidak seperti didalam sebuah perusahaan swasta dimana mencapai sebuah profit yang sebesar sebesarnya merupakan tujuan utama perusahaan. Menurut Wulandari didalam (Wiranata \& Nugrahanti, 2013) hal ini terjadi karena pemilik mayoritas cenderung bertindak untuk kepentingan sendiri sehingga akan mengorbankan kepentingan kepemilikan minoritas" dengan adanya hal ini membuat ketidakstabilan dalam penentuan arah kebijakan perusahaan itu sendiri.

Hasil penelitian ini sejalan dengan (Wiranata \& Nugrahanti, 2013)yang menyatakan bahwa kepemilikan pemerintah tidak berpengaruh terhadap kinerja perusahaan, dan penelitian ini tidak sejalan dengan (Candradewi \& Sedana, 2016)

Jurnal Insitusi Politeknik Ganesha Medan 
yang menyatakan bahwa hasil penelitian menunjukan adanya pengaruh positif dan signifikan Kepemilikan Institusional terhadap Return On Asset.

\section{Pengaruh Return On Assets terhadap Firm Value}

Hasil penelitian ini menunjukan Return On Assets memiliki nilai sektore dan berpengaruh signifikan terhadap Firm Value, maka ketika nilai Return On Assets mengalami kenaikan maka nilai Firm Value akan mengalami penurunan yang signifikan pada perusahaan sektor pertambangan batubara yang terdaftar di BEI tahun 2015-2018.

Kinerja keuangan yang baik maka seharusnya akan diikuti nilai perusahaan yang ikut naik, yang dimana harga saham akan ikut naik ketika laba meningkat. Menurut (Wedayanthi \& Darmayanti, 2016) sebagian besar investor akan berfikir sebelum menanamkan modalnya dikarenakan harga saham yang meningkat terus namun kurang konsisten dalam pencapaian laba yang diproksikan kedalam Return On Asset, sehingga hal ini kurang menjadi sebuah ketertarikan terhadap investor.

Hasil penelitian ini sejalan dengan (Ferial, Suhadak, \& Handayani, 2016) yang menyatakan bahwa Kinerja Keuangan yang digunakan sektor Return On Asset dan Return On Equity memiliki nilai sektor dan signifikan.

Hasil penelian ini tidak sejalan dengan (Ardimas \& Wardoyo, 2014) yang menyatakan hal tersebut menandakan bahwa sektor Return On Assets memiliki pengaruh yang signifikan terhadap Nilai Perusahaan.

\section{Pengaruh Kepemilikan Manajerial, dan Kepemilikan Institusional terhadap Firm Value melalui Return On Assets}

Menurut hasil penelitian analisis jalur diatas dengan adanya sektor Return On Assets sebagai sektor mediasi memiliki pengaruh sektor Kepemilikan Manajerial terhadap Firm Value. Diketahui pengaruh langsung yang diberikan Good Corporate Governance yang diproksi dengan Kepemilikan Manajerial terhadap Firm Value sebesar -0.165. Sedangkan pengaruh tidak langsung Good Corporate Governance yang diproksi dengan Kepemilikan Manajerial terhadap Firm Value yang dimediasi oleh Return On Assets adalah hasil perkalian antara nilai beta Good Corporate Governance yang diproksi dengan Kepemilikan Manajerial terhadap Return On Assets dengan nilai beta Return On Assets terhadap Firm Value, yaitu: $(-0.010) \times(-0.450)=0.005$. Maka pengaruh total yang diberikan corporate governance yang diproksi dengan Kepemilikan Manajerial terhadap Firm Value adalah pengaruh langsung ditambah dengan pengaruh tidak langsung, yaitu : ($0.165)+0.005=0.160$. Berdasarkan hasil perhitungan diatas diketahui bahwa nilai pengaruh langsung sebesar -0.165 dan pengaruh tidak langsung sebesar 0.005 yang berarti bahwa nilai pengaruh tidak langsung lebih besar dibandingkan dengan nilai pengaruh langsung, hasil ini menunjukkan bahwa secara tidak langsung Good Corporate Governance yang diproksi dengan Kepemilikan Manajerial terhadap Firm Value yang dimediasi oleh Return On Assets memiliki pengaruh.

Menurut hasil penelitian analisis jalur diatas dengan adanya sektor Return On Assets sebagai sektor mediasi memiliki pengaruh sektor Kepemilikan Institusional terhadap Firm Value. Diketahui pengaruh langsung yang diberikan Good Corporate Governance yang diproksi dengan Kepemilikan Institusional terhadap Firm Value sebesar -0,193. Sedangkan pengaruh tidak langsung Good Corporate Governance yang diproksi dengan Kepemilikan Institusional terhadap Firm Value yang dimediasi oleh Return On Assets adalah hasil perkalian antara nilai 
beta Good Corporate Governance yang diproksi dengan Kepemilikan Institusional terhadap Return On Assets dengan nilai beta Return On Assets terhadap Firm Value, yaitu: $(0,156) \times(-0.450)=-0.070$. Maka pengaruh total yang diberikan corporate governance yang diproksi dengan Kepemilikan Institusional terhadap Firm Value adalah pengaruh langsung ditambah dengan pengaruh tidak langsung, yaitu: ($0,193)+(-0,070)=-0,263$. Berdasarkan hasil perhitungan diatas diketahui bahwa nilai pengaruh langsung sebesar -0.193 dan pengaruh tidak langsung sebesar -0.070 yang berarti bahwa nilai pengaruh tidak langsung lebih besar dibandingkan dengan nilai pengaruh langsung, hasil ini menunjukkan bahwa secara tidak langsung Good Corporate Governance yang diproksi dengan Kepemilikan Institusional terhadap Firm Value yang dimediasi oleh Return On Assets memiliki pengaruh.

Hal ini dapat terjadi dikarenakan Kepemilikan Manajerial dan Kepemilikan Institusional bekerja dengan baik sehingga meningkatkan laba dan mempengaruhi nilai perushaan, dalam hal ini sektor internal yang mempengaruhi kepemilikan manajerial dalam pengambilan keputusan sehingga meningkatkan Return On Assets dan mempengaruhi Firm Value. Menurut (Pertiwi \& Pratama, 2013) sektor internal merupakan sektor yang mendorong keberhasilan dalam menerapkan Good Corporate Governance yang berasal dari dalam perusahaan, yang merupakan budaya perusahaan, peraturan dan kebijakan yang dikeluarkan perusahaan, dalam melakukan pengendalian resiko, memiliki sektor pemeriksaan yang baik, dan keterbukaan dalam inforrmasi.

\section{KESIMPULAN}

Berdasarkan hasil penelitian yang dilakukan pada perusahaan sektor pertambangan batubara yang terdaftar di Bursa Efek Indonesia dapat disimpulkan sebagai berikut : (1) Good Corporate Governance yang di proksikan dengan Kepemilikan Manajerial memiliki nilai beta -0165 dengan nilai signifikansi sebesar 0,249 lebih besar dari 0,05 $(0,249>0,05)$ artinya tidak ada pengaruh signifikan Kepemilikan Manajerial terhadap Firm Value. (2) Good Corporate Governance yang di proksikan dengan Kepemilikan Institusional memiliki nilai beta $-0,193$ dengan nilai signifikansi sebesar 0,184 lebih besar dari $0,05(0,184>0,05)$ artinya tidak ada pengaruh signifikan Kepempilikan Institusional terhadap Firm Value. (3) Good Corporate Governance yang di proksikan dengan Kepemilikan Manajerial memiliki nilai beta $-0,010$ dengan nilai signifikansi sebesar 0,952 lebih besar dari $0,05(0,952>0,05)$ artinya tidak ada pengaruh signifikan Kepemilikan Manajerial terhadap Return On Assets. (4) Good Corporate Governance yang di proksikan dengan Kepemilikan Institusional memiliki nilai beta 0,156 dengan nilai signifikansi sebesar 0,359 lebih besar dari 0,05 $(0,359>0,05)$ artinya tidak ada pengaruh signifikan Kepempilikan Institusional terhadap Return On Assets. (5) Return On Assets memiliki nilai beta -0,450 dengan nilai signifikansi sebesar 0,001 lebih kecil dari $0,05(0,001<0,005)$ artinya ada pengaruh signifikan Return On Assets terhadap Firm Value. (6) Pengaruh Good Corporate Governance yang diproksikan Kepemilikan Manajerial terhadap Firm Value yang dimediasi oleh

Return On Assets memiliki pengaruh langsung -0,165 dan pengaruh tidak langusung 0,005. Hasil ini menunjukan bahwa secara tidak langsung memiliki pengaruh signifikan. (7) Pengaruh Good Corporate Governance yang diproksikan Kepemilikan Manajerial terhadap Firm Value yang dimediasi oleh Return On

Jurnal Insitusi Politeknik Ganesha Medan 
Assets memiliki pengaruh langsung -0,193 dan pengaruh tidak langusung -0,070. Hasil ini menunjukan bahwa secara tidak langsung memiliki pengaruh signifikan.

\section{REFERENSI}

Aji, I. T. (2016). Pengaruh Struktur Kepemilikan Terhadap Return On Asset Dan Tobin's Q Perusahaan Keluarga Di Indonesia (Studi Kasus Pada Perusahaan Yang Tercatat Di BEI). Jurnal Manajemen Fakultas Ekonomi Universitas Islam Indonesia, 1-31.

Ardana, Y. (2018). Meningkatkan Kinerja Keuangan Dan Nilai Perusahaan Dalam Berinvestasi. Jurnal Ilmiah Manajemen Dan Bisnis, 19(2), 89-96.

Ardimas, W., \& Wardoyo, W. (2014). Pengaruh Kinerja Keuangan Dan Corporate Social Responsibility Terhadap Nilai Perusahaan Pada Bank Go Public Yang Terdaftar Di BEI. BENEFIT Jurnal Manajemen Dan Bisnis, 18(1), 57-66. Https://Doi.Org/10.14414/Jbb.V5i2.547

Basri, Z. (2016). Pengaruh Corporate Governance Terhadap Nilai Perusahaan Dengan Kinerja Keuangan Sebagai Variabel Intervening Pada Perusahaan Manufaktur Yang Terdaftar Di Bursa Efek Indonesia Tahun 2010-2014 Skripsi. Fakultas Ekonomi Dan Bisnis Uin Alauddin Makasar.

Candradewi, I., \& Sedana, I. B. P. (2016). Pengaruh Kepemilikan Manajerial, Kepemilikan Institusional Dan Dewan Komisaris Independen Terhadap Return On Asset. E-Jurnal Manajemen Universitas Udayana, 5(5), 31633190.

Dewi, A. S. M., \& Wirajaya, A. (2013). Pengaruh Struktur Modal , Profitabilitas Dan. E-Jurnal Akuntansi Universitas Udayana, 2(4), 358-372.

Fenandar, G. I. (2012). Keputusan Investasi, Keputusan Pendanaan, Kebijakan Dividen Dan Struktur Kepemilikan Terhadap Nilai Perusahaan Skripsi. Fakultas Ekonomi Universitas Diponegoro Semarang.

Ghozali, I. (2012). Aplikasi Analisis Multivariate Dengan Program SPSS (Edisi 5). Semarang: Badan Penerbit Universitas Diponegoro.

Hani, S. (2014). Teknik Analisa Laporan Keuangan. IN MEDIA.

Harjito, A., \& Martono. (2008). Manajemen Keuangan. Yogyakarta: Ekonisia.

Hartono, D. (2019). Metodologi Penelitian. (Publishing Zanafa, Ed.) (1st Ed.). Pekanbaru: Nusa Media.

Irmawatih, I. (2016). Analisis Faktor-Faktor Yang Mempengaruhi Good Corporate Governance Pada Pt. Adira Dinamika Multi Finance Tbk. Cabang Makassar Skripsi. Fakultas Ekonomi Dan Bisnis Uin Alauddin Makasar.

Martin, J. D., Petty, J. W., Keown, A. J., Scott, D. F., \& Haryandini. (2004). Manajemen Keuangan, Jilid 1 : Prinsip-Prinsip Dan Aplikasi (Ed. 9). Jakarta: Indeks.

Maryanti, E., \& Fithri, W. N. (2017). Corporate Social Responsibilty , Good Corporate Governance, Kinerja Lingkungan Terhadap Kinerja Keuangan Dan Pengaruhnya Pada Nilai Perusahaan Abstrak Pendahuluan. Journal Of Accounting Science, 1(1), 21-37. Https://Doi.Org/Https://Doi.Org/10.21070/Jas.V1i1.773 Januari

Munawir, H. . (2016). Analisa Laporan Keuangan (4th Ed.). Yogyakarta.

Nurkhin, A., Wahyudin, A., \& Fajriah, A. S. A. (2017). Relevansi Struktur Kepemilikan Terhadap Profitabilitas Dan Nilai Perusahaan Barang Konsumsi.

Jurnal Insitusi Politeknik Ganesha Medan 
Jurnal Akuntansi Multiparadigma JAMAL, 8(1), 1-227. Https://Doi.Org/Http://Dx.Doi.Org/10.18202/Jamal.2017.04.7038

Martin, J. D., Petty, J. W., Keown, A. J., Scott, D. F., \& Haryandini. (2004). Manajemen Keuangan, Jilid 1 : Prinsip-Prinsip Dan Aplikasi (Ed. 9). Jakarta: Indeks.

Maryanti, E., \& Fithri, W. N. (2017). Corporate Social Responsibilty , Good Corporate Governance, Kinerja Lingkungan Terhadap Kinerja Keuangan Dan Pengaruhnya Pada Nilai Perusahaan Abstrak Pendahuluan. Journal Of Accounting Science, 1(1), 21-37. Https://Doi.Org/Https://Doi.Org/10.21070/Jas.V1i1.773 Januari

Munawir, H. . (2016). Analisa Laporan Keuangan (4th Ed.). Yogyakarta.

Nurkhin, A., Wahyudin, A., \& Fajriah, A. S. A. (2017). Relevansi Struktur Kepemilikan Terhadap Profitabilitas Dan Nilai Perusahaan Barang Konsumsi. Jurnal Akuntansi Multiparadigma JAMAL, 8(1), 1-227. Https://Doi.Org/Http://Dx.Doi.Org/10.18202/Jamal.2017.04.7038

Pertiwi, T. K., \& Pratama, F. M. I. (2013). Pengaruh Kinerja Keuangan, Good Corporate Governance Terhadap Nilai Perusahaan Food And Beverage. Jurnal Manajemen Dan Kewirausahaan, 14(2), 118-127.

Rambe, H. M. F., Gunawan, A., Julita, Parlindunga, R., \& Gultom, D. K. (2017). Pengantar Manajemen Keuangan. Medan: Perdana Mulya Sarana.

Riyanto, B. (2010). Dasar-Dasar Pembelajaran Perusahaan. Yogyakarta: Penerbit BPFE.

Sanjaya, S., \& Jufrizen, J. (2017). Peran Moderasi Kepemilikan Intitusional Terhadap Determinan Return On Equity Di Bursa Efek Indonesia. Jurnal Ilmiah Manajemen dan Bisnis, 18(2), 189-205.

Sari, M., \& Jufrizen, J. (2019). Pengaruh Price To Earning Ratio, Debt To Equity Ratio, Return On Asset Dan Price To Book Value Terhadap Harga Pasar Saham. Jurnal KRISNA: Kumpulan Riset Akuntansi, 10(2), 196-203.

Sutedi, A. (2012). Good Corporate Governance. (Tarmizi, Ed.) (Ed. 1). Jakarta: Sinar Grafika.

Wahyudi, U., \& Pawestri, H. P. (2006). Implikasi Struktur Kepemilikan Terhadap Nilai Perusahaan: Dengan Keputusan Keuangan Sebagai Variabel Intervening. Simposium Nasional Akuntansi 9 Padang, 1-25.

Wahyuni, S. F. (2018). Pengaruh Pengungkapan Corporate Social Responsibility Terhadap Nilai Perusahaan Dengan Profitabilitas Sebagai Variabel Moderasi. Maneggio : Jurnal Ilmiah Magister Manajemen, 1(1), 109-117. 